\title{
KH. MUHAJIRIN AMSAR CONTRIBUTION ON LEGAL HADITH INTERPRETATION
}

\author{
Masykur Hakim \\ A Lecturer at the Faculty of Ushuluddin, The State Islamic University \\ of Syarif Hidayatullah Jakarta
}

\section{Abstrak}

Ada perbedaan dan kesamaan yang menonjol kaitannya dengan penjelasan hadist tentang tidur dan wudhu dalam kitab Subul al-Salam dan Misbah al-Dhalam. Al-Shana'niy menjelaskan hadits tersebut dengan pendekatan tatabahasa atau gramer sebelum menjelaskan isinya. Sementara KH Muhajirin Amsar menjelaskan hadits dengan mengabaikan pendapat ulama lainnya dalam hal tata bahasa, sehingga pembaca dapat langsung memahami isi hadits. Dia juga tidak memberikan pendapatnya sendiri setelah pendapat ulama, tampaknya ia lebih cenderung menempatkan pembaca untuk memilih secara bebas karena masalah sebagai isu khilafiyyah. Masing-masing memiliki nilai tambah tersendiri dan telah membuat kontribusi yang signifikan dalam konteks penjelasan hukum hadis yang terdapat dalam kitab Bulughal-Maram termasuk $\mathrm{KH}$ Muhajirin Amsar, Para ulama Betawi asli.

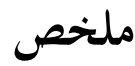

كتاب سبل السلام ومصباح الظلام يبينان أن كلي المحاضرين أوجها التشابه والاختلاف في البيان. أوجهه تشاهكلي العالمين ينقسم إلى ثماني نقاط في الرأي بشأن مع الحديث ذي الصلة إلى مسألة النوم والوضوء. والفرق هو أن الصنعاني شرح شروط الحديثالنحوية قبل شرح احتواء له، ثم يقدم رأيه الشخصي بعد رأي العلماء السابقين الآخرين •في حين أوضح الأستاذ الحج مهارين أمسرالحديث بتجاهل رأي العلماء الآخرين من حيث قواعد اللغة، بحيث يمكن للقارئ أن يفهم على الفور مضمون الحديث. كما انه لم يقدم رأيه الشخصي بعد رأي الباحثين، يبدو أنه من المرجح الذي وضع القارئ أن يختار بكرية بسبب مشكلة مثل قضية الخلاف . كل لديه القيمة 


\section{المضافة الخاصة بها وقدم مساهمة كبيرة في سياق وصفالحديث القانوين الذي ورد في كتاب بلوغ المرام بما في تلك المساهمةالأستاذ الحجج مهارين أمسر، العالم البيتاوي الأصلي.}

Keywords: Muhajirin Amsar, Subul al Salam, Misbah al-Dhalam, and Interpretation

\section{A. Introduction}

The word 'contribution' is originally derived from English word which means to help or donations, for example "His contribution to art literature was very great, which means very large contribution to the literature. Or a meaningful contribution to charity which equal understanding to donation stocharity. ${ }^{1}$

Furthermore, etymologically speaking the word 'sharh' (interpretation) is derived from the Arabic sharaha which means 'to explain', 'to open', 'and to pave'. ${ }^{2}$ And too, the word 'sharh' is usually used to describe the meaning of the hadith, while the word 'tafsir' is usually used to explain the meaning of the Qur'an. For the implementation, the word tafsir is exclusively concerning with the interpretation of the qur'anic meaning. While sharh, relies on hadith interpretation, its content, conclusion (istinbath) for both legal and moral of the Prophet's words, or explaining other disciplines. ${ }^{3}$

Meanwhile, according to the definition the word sharh hadith is as follows:

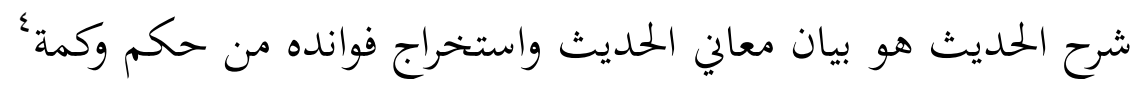

(Sharh hadith is to explain and to interpret the meaning of all its contents of hadith both legal and wisdom).

1 Peter Salim, The Contemporary English-Indonesian Dioctionary, (Modern English Press, Jakarta), p.403.

2 Muhammad bin Mukarram bin Al-Manzhur al-Afriqi al-Misrhi, Lisan al-Arab (Beirut: Dar Shadr, Vol. 2,), pp.497-498.

3 Nizar Ali, (Ringkasan Disertasi), Kontribusi Imam Nawawi Dalam Penulisan Syarh Hadits, (Yogyakarta, 2007), p.4.

4 Mujiono Nurcholish, Metodologi Syarh Hadits, (Bandung: Fasygil Group, 2003) p.3 
The definition very much relies on the matan of hadith whereas sharh includes all components of hadith, both sanad and matan is as follows: ${ }^{5}$

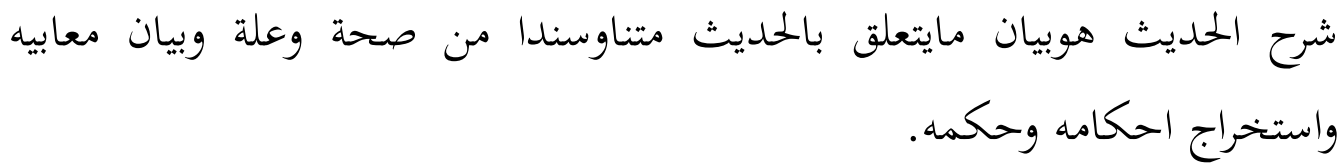

(Sharh hadith is to explain the validity and disability the sanad (chain of hadith narrators) and matan hadith as well as its meaning, and conclusion to both legal and wisdom)

With the above definition, the hadith interpretation (sharh) broadly covers the following three important points:

1. Describing the both quantity and quality of hadith, in terms of the sanad or the matan, both in general and detail. This includes the explanation of its path ways, origin, identity and characteristics of the narrators, as well as analysis of the matan in the view language rules.

2. Elaborating the meaning and intention of hadith, which include the explanation how to read the specific pronounciation, grammatical, lexical and each intended meaning.

3. Discovering the law and wisdom contained there in which includes istinbath toward the law and the wisdom in hadith, either expressed or implied. ${ }^{6}$

The interpretation (sharh) of hadith also means researching, then explaining each component contained in hadith. In general, the hadith scholars describe two components namely the sanad and the matan. The sanad is a series of narrators who transmit the matan from primary sources. While the matan is hadith narration as the supporting elements of its meaning. ${ }^{7}$

\section{B. History and Development of Sharh Hadith}

Historical development of sharh hadith experiencing a long story and dynamic. Hasbi al-Shiddiqy ${ }^{8}$ found sharh hadith developments occurred in

\footnotetext{
Mujiono Nurcholish, Metodologi Syarah Hadits, p.3

6 Mujiojo Nurcholish, Metodologi Syarah Hadits, p.4

7 Ajaj al-Khatib, Usul al-Hadits, (Jakarta: GMP, 2007) p.12

8 Hasbi al-Shiddiqy, Sejarah Pengantar ilmu Hadits (Bulan Bintang, Jakarta, 1980) pp.46-47
} 
the seventh period or the last period of the development of the hadith and its sciences. The Seven periods made by Hasbi Al-Shiddiqy are as follows: 1) the birth of the hadith up to the Prophet passed away; 2) the restriction of hadith narration; 3) the development and the journey of compiling hadith narration, since the late $41 \mathrm{AH}$ up to $1 \mathrm{AH} ; 4)$ The codification of hadith in the second Centuy AH.; 5) The screening and selection of hadith in the $3^{\text {rd }}$ century of $\mathrm{H}$; 6) The codification of the forgotten hadiths since the beginning of the fourth century up to $646 \mathrm{AH} ; 7)$ the Writing books of sharh, takhrij and so it began in the middle of seventh century AH. ${ }^{9}$

As for Muhammad Abdul Aziz al-Khuli divides sharh hadith development phase into five periods, and the last period is systematization, compilation, and writing the book sharh since the fourth century AH. ${ }^{10}$ While Other hadith figure, Nuruddin 'Itr divides the history of the science of hadith into seven phases; 1) the birth of the hadith sciences since the companions period up to the hundredth century $\mathrm{AH}$; 2) the completion, since the beginning of the second century to the beginning of the third century $\mathrm{AH} ; 3$ ) the compilation hadith sciences books separately, since the third century until the middle of the fourth century $\mathrm{AH} ; 4$ ) the compilation of main books of hadith sciences since the middle of the fourth until the seventh century $\mathrm{AH}$; 5) the maturation and refinement of of hadith sciences since the end of the seventh century until the tenth century $\mathrm{AH}$; 6) the stagnation, since the tenth century to the fourteenth century $\mathrm{AH} ; 7$ ) the second resurrection since the fourteenth century $\mathrm{AH}$ and so on. ${ }^{11}$

Pragmatically speaking, the sharh hadith has actually occurred at the birth of the hadith itself, namely by the Prophet verbally and continued during the period of companions by the scholars, so the periodization of the history of sharh hadith seems necessary to be distinguished to the historical periodization of the development of the hadith sciences and the hadith itself. Many facts prove that sharh hadith verbally is often done by the Prophet and the companions. Therefore, the period of the historical development of sharh hadith mainly divided into three periods; are at the time of sharh hadith at the time of the early period of hadith (fi' asr al-risalah), sharh hadith at the time of hadith narration and

9 Hasbi Al-Shiddiqy, Sejarah Pengantar Ilmu Hadits, p.47

${ }_{10}$ Muhammad Abdul Aziz al-Khyuli, Tarikh Funun al-Hadits (Jakarta, Dinamika Berkah Utama, tt) p.12

11 Nuruddin 'Itr, Manhaj al-Naqd fi ‘Ulum al-Hadits (Beirut, Dar al-Fikr, 1979) p.72 
compilation (fi ashri al-riwayah wa al-tadwin), and sharh hadith after the period of the compilation (ba'daal-tadwin). ${ }^{12}$ The latter of those periods is the time when the emergence of several books began such as Sharh Hadith Bukhariy, Fath alBariy by IbnHajar al-'Asqalaniy, Umdat al-Qariyby Badruddin al-'Ainiy, Irshad al-Sariyby Al-Qathalaniy, Faid al-Bariy by Nur Shah Anwar al-Kasymiriy, and so on for sharh hadith books.

As it is known that Bulugh al-Maram by Ibn Hajar al-Asqalaniy ${ }^{13}$ concerning with the legal aspects of hadith which has several sharh books, such as Subul al-Salam, ${ }^{14}$ the work of Al-Shan'aniy and Misbah al-Dhalam by KH.Muhajirin Amsar. The discussion is focused on Misbah al-Dhalam, ${ }^{15} \mathrm{KH}$ Muhajirin Amsar's work and his methods in explaining the legal aspects of hadith, Although it is possible to discuss other methods other than the author's book of Sharh Bulugh al-Maramin his early time such as as Al-Sha'aniy.

\section{The Compiler of Bulugh al-Maram}

The compiler of Bulugh al-Maram is Ahmad ibn Ali ibn Muhammad Abu alFadl al-Kannaniy al-Syafi' ie known as Ibn Hajar al-' Asqalaniy, a gonfalonier for sunnah, justices, hafidz and hadith narrator. He was born in Egypt in Sha'ban773 $\mathrm{AH}$. In the country where he grew up, he memorized the Qur'an, al-Hawiy, and a summary of Ibn al-Hajib. He sailed to accompany one of his closest colleague to Mecca, hardly learned hadith and love the subject. He earnestly studied and obtained from the experts in a number of countries such as Hejaz, Sham, and Egypt, especially he learned to Al-Bulqaini and Ibn al-Mulaqqan in Iraq and finally they gave him authorization to teach and give fatwa. He also learned Islamic legal theory to al-'Izz bin Jamaah, the language to al-Majd Fairuzabadiy, Arabic to al-Imariy, literature and arudl to al-Badr al-Busytakiy. Then he tried to spread the hadith and consistently engaged in it to several places, either through teaching or compilation of books for more than 21 years. ${ }^{16}$

As for his writing not less than 150 titles, and some of which are related to

12 Mujiono Nurcholish, Metode Syarah Hadits, h.35.

13 Ibn Hajar Al' Asqalaniy, Bulugh al-Maram,

14 Muhammad ibn Ismail al-Amir al-Yamaniy al-San'aniy, Subul al-Salam, (Delhi, India)

15 Muahmmad Muhajirin Amsar al-Dariy Bekasi, Misbah al-Dhalam.

16 Muhammad bin Ismail al-Amir al-Yamani al-San'aniy, Subul Al-Salam, (Maktabah Isya' at al-Islam, Delhi, India), p. 3 
the disciplines of hadith such as Al-Isabah fi Asma al-Sahabah, Tahdizb al-Tahdheeb, Al-Taqrib, Ta'jilal-Manfaah bi Rijal al-Arba'ah, Musytabih al-Nisbah, Talkhish alKabirfi Takhrij Ahadith al-Rafi'ie al-Kabir, Takhrij al-Masabih and Ibn Hajib, Takhrij al-Kassyaf, Ittihaf al-Maharah, Al-Muqaddimah, Badl al-Ma 'un, Nukhbah al-Fikr and its interpretation, and the most monumental in this field is Fath al-Bariy fi Sharh Sahih al-Bukhariy. After compiling this sunnah encyclopedia, he passed away after isha' time on Saturday evening of 18th of DhulHijjah in 852 AH. ${ }^{17}$

\section{A Biography of KH Muhajirin Amsar}

Misbah al-Dzalam compiler is Muhajirin Amsar al-Dariy, Betawi scholar and religious expert (ulama), born in Kampung Baru Cakung Barat, Cakung, East Jakarta on November 10, 1921. The name al-Dariy is originally taken from Ma'had Dar al-Ulum, where he studied at Mecca. The most of its alumni made the use of the name al-Dariy behind each name.

Muhajirin Amsar learned to several scholars as can be noted to Guru Asmat in his homeland, Kampung Baru Cakung Barat, H. Mukhayar, H. Ahmad, KH Hasbiallah Klender, H. Anwar, H. Hasan Murtaha, Sheikh Muhammad Tahir Ahmad ibn Muhammad, the disciple of Shaykh Mansur KH Salih Ma'mun Banten, KH Abdul Majid and Habib Ali Kwitang. Then he continued his formal education at Dar al-Ulum al-diniyyah, Mecca Saudi Arabia from 1947 up to 1955. While in Mecca he also enrolled in the foyer of Masjid al-Haram and every summer he learned in Masjid Nabawi in Medina. ${ }^{18}$

In addition to his teaching at his religious school (Pesantren) Al-Nida AlIslamiy Bekasi and some places outside the Pesantren, $\mathrm{KH}$ Muhajirin Amsar diligently wrote the book in a variety of themes, ranging from hadith sciences, Islamic jurisprudence, logic, theology, and so forth, which were written in Arabic. Among the works he wrote as the following:

1. Mishbah Al-Dzalam Syarh Bulugh al-Maram, 8 volumes, on syarah hadits related with legal interpretation.

2. Idhah al-Maurid, 2 volumes on Islamic legal theory.

3. Fan al-Mathla'ah, 3 volumes,on Arabic grammatical.

17 Al-Sana'niy, Subul al-Salam, p. 4

18 Ahmad Fadli HS, Ulama Betawi, (Manhal al-Nasyi' in Press, Jakarta, 2011) p.186 
4. Qawaid al-Nahwiyyah, 2 volumes, on Arabic grammatical.

5. Mahfuzaton Arabic.

6. Al-Bayan on Arabic.

7. Mukhtarat al-Balaghah on Arabic.

8. Mulakhkhash al-Ta'liqat 'ala Matn al-Jauhariyah, on Islamic theology.

9. Syarh Ta'liqat 'ala Matn al-Jauhariyah on Islamic theology.

10. Taisir al-Wushul fi ilm al-Ushul, on Islamic legal theory.

11. Istikhraj al-Furu' 'ala al-Ushul, on Islamic legal theory.

12. Khilafiyyah on Islamic legal theory.

13. Filsafah al-Tasyri'on Islamic legal theory.

14. Ma'rif Thuruq al-Ijtihad on Islamic legal theory.

15. Takhrij al-Furu' 'ala al-Ushul on Islamic legal theory.

16. Al-Qaul al-Hasis fi Mushthalah al-Hadison hadith sciences.

17. Ta'liqat Ala Matn Al-Bayquni on hadith sciences.

18. Al-Istidzkar fi Taqyid Mala Budda Min Thsalat al-Anwaron hadith sciences.

19. Al-Madarik fi Al-Mantiqon logic.

20. Al-Nahj al-Mathlub fi Al-Manthiq al-Marghubon logic.

21. Al-Qaul al-Faid fi Ilm Al-Faraidon inheritance sciences.

22. Mar'at Al-Musliminon history.

23. Al-Muntakhab min TarikhDaulahBanilmayyahon history.

24. Tarikh Al-Adab Al-Arabyon history of Arabic literature.

25. Tarikh Muhammad Rasulillah Saw wa Khulafa al-Rasyidin on history.

26. Al-Tanwir fi-Ushul Al-Tafsir on tafsir al-Qur'an sciences.

27. Tatbiq Al-Ayat bi al-Hadith on tafsir al-Qur'an sciences.

28. Qawaid al-Khams al-Bahiyyah on Islamic legal theory.

29. Al-Saqayah al-Mar'iyyahfi al-Bahswa al-Munadzarah on the methods of debate.

30. Al-Qur'u Al-Sam'ufi al-Wudhuon wudhu' procedures.

31. Al-Ta'aruffi al-Tasawuf on Sufism. ${ }^{19}$ 


\section{E. KH. MuhajirinAmsar and The Chain of Narrators (sanad) of Hadith Bulugh al-Maram}

Ibn Al-Mubarak stated; isnad or sanad is an important part of Islam, even if the absence of the sanad surely everyone can conveys freely. ${ }^{20}$ Here is the sanad of KH.Muhajirin Amsar in learning the hadith that he obtained the so called 'ijazah' to teach hadith contained in the book of Bulugh al-Maram to others.

He learned hadiths Bulugh al-Maram to sheikh Muhammad Yasin al-Fadaniy al-Makkiy, sheikh Muhammad Yasin Ali bin Husin al-Malikiy, Al-Sayyid Abiy Malikiy Syatha Bakr Al-Makkiy, Al-Makkiy of Sayyid Ahmad ibn Zainiy Dahlan Al-Makkiy, Zainiy Dahlan of Uthman ibn Hasan al-Dimyathiy, AlDimyathiy of Abdullah ibn al-Syarqowiy Hejaziy, Al-Syarqowie of Al-Shams Muhammad bin Salim Al-Ziyadiy, Al-Ziyadiy of Al-Shams Muhammad ibn al 'ala al-Babiliy, Al-Babiliy of Salim bin Mohammed Al-Nahuriy, Al-Nahuriy of Al-Najm Muhammad Ahmad al-Ghaithiybn, Al-Ghaithiy of al-Qadhiy Zakariya ibn Muhammad al-Anshariy, Zakaria al-Anzhariy of Ahmad al-Haafizibn Ali ibn Hajar al-Asqalaniy, the compiler of Bulugh al-Maram. ${ }^{21}$

\section{F. KH. Muhajirin Amsar Method in His Book, Misbah al-Dhalam}

The word method is derived from English, method which means a planned and orderly way to do something, such as His method of teaching is very up to date which meant his teaching method is very modern way. ${ }^{22}$ Here is the method used by KH Muhajirin Amsar in explaining the meaning of the hadith concerning with sleep which could abrogate the matter of wudlu'.

The hadith text concerning with sleep which could abrogate wudlu'

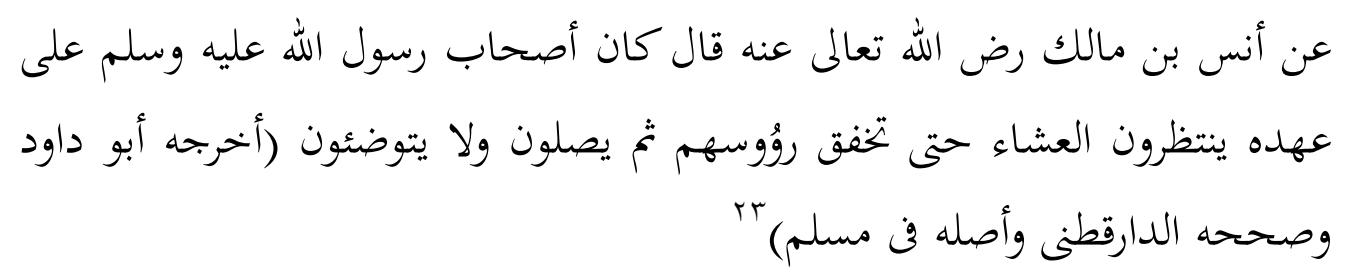

\footnotetext{
20 Mahmud Tahhan, Taisir Mustalah al-Hadits,

21 Muhammad Muhajirin Amsar, Misbah al-Dhalam, p.6

22 Peter Salim, The Contemporary English-Indonesian Dictionary, pp. 167

23 Muhammad Muhajirin Amsar, Misbah al-Dhalam, p.73
} 
It is clear that the person who sleeps in his sitting does not abrogate his wudlu', both long and short sleep, as long as he does not make any moves from his seat. This relies on Syafi'e school of thought, Malik, Ahmad. Ashab al-Ra'yi argued briefly when the person sleeps longer, it will definitely abrogate his wudlu'.

On the matter of sleep which related to someone's wudlu', there are vary in idea which rely on eight schools of thought. First, sleeping is not abrogating wudlu' whatever the circumstances, as it is narrated from Abu Musa Al-Asy'ariy, Sa'id ibn Musayyab, Abu Majlaj and others. Second, sleeping can abrogate the wudlu' regardless the sleep is much or little. Nawawi said that this opinion relies on Hasan Basri, al-Muzniy, and Abu Ubaid al-Qasim. Third, sleeping which takes much in time can abrogate the wudlu'whatever the circumstances. Nawawi said that this opinion relies on Malik, Ahmad in one of his narration. Rabi'a, Zuhri and Auza'i tend to this school of thought.Fourth, if the sleeping in one pattern of those who pray like people are bowing, prostration and standing is not abrogating it, either in or outside the prayer (salat). If the sleep lies or supine can also abrogate it. Nawawi said that this stand point very much relies on Abu Hanifa, Daud schools of thought and the statement of Syafi'e. Fifth, the matter does not abrogate it except it occurred in bowing and prostration. The idea relies on Ahmad narration. Seventh, the matter is not abrogate it in all circumstances and abrogate it outside the prayer (salat). This opinion is attached to Zaid bin Ali and Abu Hanifa.Eighth, if the matter occurred firmly on the seat does not abrogate it,either sleep takes much in time or little and in or outside the prayer.This idea relies on Syafi'e. ${ }^{24}$

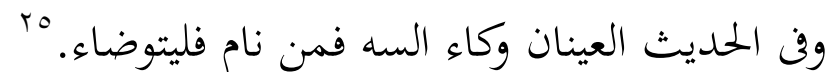

The above hadith shows that both eyes are bound to the rectum. If the person slept it would tie it apart and he did not know what matches out of the rectum. If the mentioned hadith general in meaning then it devoted to the hadith which relies on the bowed head. Therefore, the hadith compatibility with the translation of the hadith that sleeping in the waiting prayers caused things were

${ }^{24}$ Muhammad Muhajirin Amsar, Misbah Al-Dhalam Vol. 1, p.74

25 Muhammad Muhajirin Amsar, Misbah al-Dhalam Vol. 1, p.74 
not moving in. So that the seat does not abrogate it. The hadith in the context of waiting for prayer time at the night of Ramadan. ${ }^{26}$

Another example is the hadith related to the qunut in shubuh prayer time which reads

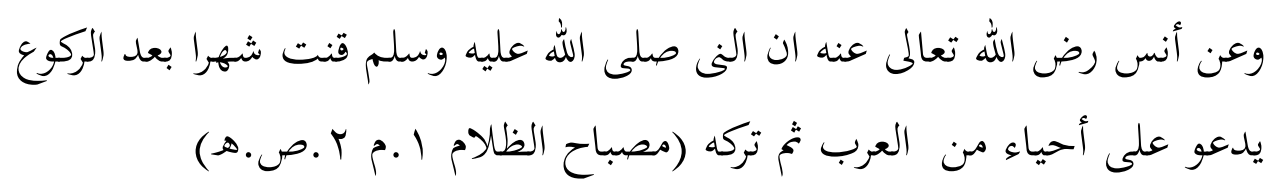

From Anas RA narrated that the Prophet did perform the qunut for a month after bowing to pray for the Arab residents of one village, then he left, (Muttafaq'alaihi).

Baqi Ahmad and Daruquthni from other narration added as for the subuh prayer of the Prophet always do the qunut up to his passed away.

KH Muhajirin explained the matter as follows; Muslims agreed to the hadith related to the matter of the qunut then agreed that Zuhur, Asar, Maghrib and Isha, the Prophet did not do the qunut unless there is a disaster (nazilah) and a dispute occurred at subuh for the prayer time.

With this hadith al-Shafi' i argued that the matter of the qunut is recommended caused the Prophet did it up to his passing away and it was part of the sunnah $a b^{\prime} a d h$ that if the matter is forgotten need to be equipped by performing the so called the sujud sahwi.

$\mathrm{KH}$ Muhajirin said that he received a sequential manner (musalsal) of the hadith related to the matter of the qunut dawn of his lecturer, Muhammad Yasin. He said that in concatenated he received Syafi'iyyah and not from other scholars. Malik said, the Prophet do perform the qunut before bowing. The differences of opinion occurred between Syafi'iyyah and Malikiyyah that the performance of the qunut after bowing or before it. However, they agreed upon the matter of prescribing the qunut. Abu Hanifah, Ahmad and al-Tsauriy said that the matter was not recommended, mainly in subuh and other times except the prayer of witir. As the matter of the qunut nazilah they agreed to its existence caused the Prophet did it for about a month then left it. ${ }^{27}$

${ }^{26}$ Muhammad Muhajirin Amsar, Misbah al-Dhalam Vol. 1, p.75

${ }_{27}$ KH.Muhajirin Amsar, Misbah al-Dhalam Vol. 2, p.51. 
The qunut means prayer while standing in the prayer for a specific place. Syafi'iyyah said that the qunut moment is after bowing at the last cycles (rakaat). The qunut is indeed recommended loudly at the jahar prayer and silent while at the sir. ${ }^{28}$

Providing the interpretation for the same hadith, Al-Shan'aniy said that Anas ibn Malik was asked whether the Prophet did the qunut before or after bowing. He said that the Prophet did it after bowing for a month, after he saw that 70 people whom he sent to the polytheists were killed and the Prophet prayed for the shuhada (martyrs).Several hadiths that narrated by Anas related to the matter seem contradict each other, then Al-Shan' aniy collected all of hadiths and found all are authentic hadith. ${ }^{29}$ The qunut was done before bowing or later, he said that the qunut which done before bowing caused of the performance of a longstanding for reciting the surahs of the Qur'an. He said that the best of which is the establishment of long prayers. The qunut which performed by the Prophet after bowing in prayer had been done for a month.Then continued this practice until he passed away. If the the long standing in his prayer, indeed caused of reciting the Qur'an and praying at the same time, said Al-Shan'any that Anas seems disagreed upon the matter of the Prophet who habitually do the qunut in subuh prayer time in his life, up to his passed away. The long standing in prayer is generally applicable to all the five times prayers a day. ${ }^{30}$

As for the hadith of Abi Hurairah RA.which is selected and edited by alHakim that the Prophet when lifting his head from bowing in the second rakaah at subuh prayer time, he raised his hands and prayed; AllahummaIhdini fi Hadaita until the end. Abdullah bin Said al-Maqbariy found that praying in the second rak'ah at shubuh prayer time is habits for the Salaf and Khalaf, AlHadiy, Al-Qasim, bi Zaid Ali and Al-Shafi'i although differed in narrating the pronunciation. Al-Hadiy with praying that adopted from the Qur'anic verses by reciting and Al-Syafi'ie read "AllahummahfimaHadaita until the end." 31

\footnotetext{
${ }^{28}$ KH Muhajirin Amsar, Misbah al-Dhalam Vol. 2, p. 52

29 Al-Shan'aniy, Subul al-Salam Vol. 1, p.317

30 Al-Shan'aniy, Subul al-Salam Vol. 1, p.317

31 Al-Shan'aniy, Subul al-Salam Vol. 1, p.317
} 


\section{G. Conclusion}

Referring to the above methods used in the two books of sharh, Subul alSalam and Misbah al-Dhalam show that both lecturers have similarities and differences in explanation. The similarities of the both scholars devide into eight points of opinion concerning with the hadith related to the matter of sleep and wudhu'. The difference is that Al-Shana' niy explained the hadith in terms of grammar before explaining its contain, then he provides his own opinion after the other earlier scholars opinion. While KH Muhajirin Amsar explained hadith by ignoring other scholars opinion in terms of grammar, so that the reader can immediately understand the content of the hadith. He also did not provide his own opinion after the scholar's opinion, it seems he more likely put the reader to choose freely due to the problem as the issue of khilafiyyah. Each has its own added value and has made a significant contribution in the context of hadith legal description that contained in the book of Bulughal-Maram including $\mathrm{KH}$ Muhajirin Amsar, The native Betawi scholars. Wallahua'lam Bi al Shawab.

\section{BIBLIOGRAPHY}

Al' Asqalaniy, Ibn Hajar.Bulugh al-Maram

Ali, Nizar. 2007. Kontribusi Imam Nawawi Dalam Penulisan Syarh Hadits. Yogyakarta: Ringkasan Disertasi

Al-Khatib, Ajaj. 2007. Usul al-Hadits, (Jakarta: GMP, 2007)

Al-Misrhi, Muhammad bin Mukarram bin Al-Manzhur al-Afriqi.tt. Lisan alArab, Beirut: Dar Shadr, Vol. 2

Al-San'aniy, Muhammad bin Ismail al-Amir al-Yamani. tt. Subul Al-Salam, Delhi, India: Maktabah Isya'at al-Islam

Al-San'aniy,Muhammad ibn Ismail al-Amir al-Yamaniy, Subul al-Salam, (Delhi, India,

Al-Sana'niy, Subul al-Salam

Al-Shiddiqy, Hasbi. 1980. Sejarah Pengantar ilmu Hadits, Jakarta: Bulan Bintang Amsar, KH Muhajirin. tt. Misbah al-Dhalam, Vol. 2

Amsar, Muhammad Muhajirin. tt. Misbah al-Dhalam Vol. 1

Bekasi, Muahmmad Muhajirin Amsar al-Dariy. tt.Misbah al-Dhalam.

Fadli, Ahmad HS. 2011. Ulama Betawi, Jakarta: Manhal al-Nasyi'in Press 
Muhammad Abdul Aziz al-Khyuli. tt. Tarikh Funun al-Hadits, Jakarta: Dinamika Berkah Utama

Nurcholish, Mujiono.2003. Metodologi Syarh Hadits, Bandung: Fasygil Group

Nuruddin 'Itr. 1979. Manhaj al-Naqd fi 'Ulum al-Hadits, Beirut, Dar al-Fikr

Salim, Peter. tt. The Contemporary English-Indonesian Dioctionary, Jakarta: Modern English Press

Tahhan,Mahmud. tt.Taisir Mustalah al-Hadits 
226 Millah Vol. XV, No. 2, Februari 2016 